\title{
Saccharococcus caldoxylosilyticus sp. nov., an obligately thermophilic, xylose-utilizing, endospore-forming bacterium
}

\author{
Shafiq Ahmad, ${ }^{1}$ Robert K. Scopes, ${ }^{1}$ Gavin N. Rees ${ }^{2}$ and Bharat K. C. Patel ${ }^{3}$
}

1 School of Biochemistry, La Trobe University, Bundoora, Melbourne, VIC 3083, Australia

2 CRC Freshwater Ecology, Murray-Darling Freshwater Research Centre, Albury, NSW 2640, Australia

3 School of Biomolecular \& Biomedical Sciences, Griffith University, Nathan Campus, QLD 4111, Australia

\author{
Author for correspondence: Robert K. Scopes. Tel: +61 39479 2196. Fax: +61 394792467. \\ e-mail: R.Scopes@1atrobe.edu.au
}

\begin{abstract}
Several closely related, xylanolytic, thermophilic bacilli were isolated from local soils on xylose-containing minimal medium. On the basis of morphology and biochemical characteristics, one of the isolates, designated strain $\mathrm{S}^{1812^{\top}}$ ( $T$ = type strain), was studied further. Strain $S 1812^{\top}$ was a xylanolytic, sporulating, Gram-positive, rod-shaped bacterium. Its Gram-positive nature was confirmed by electron microscopic examination of thin sections of the cells. The isolate was a thermophilic (optimum temperature for growth, $65^{\circ} \mathrm{C}$ ), facultative anaerobe that grew on a wide range of carbon sources including glucose, lactose, starch and xylose. It expressed high levels of both xylose isomerase and xylulokinase on xylose and also on glucose. The DNA G+C content was $44 \mathrm{~mol} \%$. rRNA gene sequence analysis placed strain $\mathrm{S}_{1812}{ }^{\mathrm{T}}$ in Bacillus cluster 5; it was more closely related to Saccharococcus thermophilus than to thermophilic Bacillus species. DNA-DNA hybridization also indicated its close relationship to $S$. thermophilus. Based on the evidence presented, it is proposed that strain $\mathrm{S}^{1812}{ }^{\top}$ be designated Saccharococcus caldoxylosilyticus

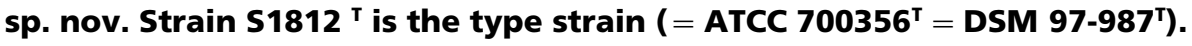

Keywords: Saccharococcus caldoxylosilyticus, Saccharococcus, obligate thermophile, phylogeny, xylanolytic

\section{INTRODUCTION}

It is now over a century since thermophiles were first reported (Miquel, 1888). Over the years, a number of spore-forming thermophiles have been reported, mainly in the genera of Bacillus and Clostridium. Many strains of the thermophile Bacillus stearothermophilus have been described, and proteins isolated from them have been extensively characterized. Most such strains have temperature optima below $60^{\circ} \mathrm{C}$, though some less-characterized bacilli grow successfully at temperatures up to $75^{\circ} \mathrm{C}$ (e.g. Guagliardi et al., 1996).

In the search for a suitable thermophilic species that would ferment pentose sugars such as those in lignocellulose hydrolysates, local soils were sampled for strains that would grow at $65{ }^{\circ} \mathrm{C}$ on a minimal medium supplemented with xylose. A suitable strain would preferably convert the sugars to ethanol or would have

The GenBank accession number for the $16 \mathrm{~S}$ rDNA sequence of strain $\mathrm{S} 1812^{\top}$ is AF067651. the potential to be modified by genetic manipulation to produce ethanol (Neale et al., 1988). The most rapidly growing colonies were selected and an aerobic bacillus was isolated. Based on preliminary experiments, this strain appeared to differ from other thermophilic bacilli, and therefore was characterized further. The present paper describes its isolation, biochemical pattern, 16S rRNA sequence, $\mathrm{G}+\mathrm{C}$ content, morphology and DNA-DNA hybridization with close relatives and proposes that it be designated a new species of the genus Saccharococcus.

\section{METHODS}

Sample source. Samples were collected from local soil (Melbourne, Australia) in small vials and stored at $5^{\circ} \mathrm{C}$ until inoculation in the medium.

Enrichment and isolation. Enrichments were initiated by adding $0 \cdot 1-0 \cdot 2 \mathrm{~g}$ sample to minimal medium (MM) that contained $1 \%$ xylose as the sole carbon source followed by incubation at $65^{\circ} \mathrm{C}$ for up to $24 \mathrm{~h}$. MM contained $\left(\mathrm{g} \mathrm{l}^{-1}\right)$ : $\mathrm{K}_{2} \mathrm{HPO}_{4}, 4 \cdot 0 ; \mathrm{KH}_{2} \mathrm{PO}_{4}, 1 \cdot 0 ; \mathrm{NH}_{4} \mathrm{NO}_{3}, 1 \cdot 0 ; \mathrm{NaCl}, 1 \cdot 0$; and $\mathrm{MgSO}_{4}, 0 \cdot 25$; it also contained trace mineral solution 
$\left(10 \mathrm{ml} \mathrm{l}^{-1}\right)$ and the $\mathrm{pH}$ was adjusted to $6 \cdot 8$. Trace mineral solution contained $\left(\mathrm{g} \mathrm{l}^{-1}\right)$ : EDTA, $5 \cdot 0 ; \mathrm{CaCl}_{2} .2 \mathrm{H}_{2} \mathrm{O}, 6 \cdot 0$; $\mathrm{FeSO}_{4} .7 \mathrm{H}_{2} \mathrm{O}, 6 \cdot 0 ; \mathrm{MnCl}_{2} .4 \mathrm{H}_{2} \mathrm{O}, 1 \cdot 15 ; \mathrm{CoCl}_{2} .6 \mathrm{H}_{2} \mathrm{O}, 0 \cdot 8$; $\mathrm{ZnSO}_{4} .7 \mathrm{H}_{2} \mathrm{O}, 0.7 ; \mathrm{CuCl}_{2} .2 \mathrm{H}_{2} \mathrm{O}, 0.3 ; \mathrm{H}_{3} \mathrm{BO}_{3}, 0.3$; and $\left(\mathrm{NH}_{4}\right)_{6} \mathrm{Mo}_{7} \mathrm{O}_{24} \cdot 4 \mathrm{H}_{2} \mathrm{O}, 0 \cdot 25$.

After two transfers of $1 \mathrm{ml}$ growing culture into fresh medium, culture purification was performed by isolating single colonies on MM agar plates (MM containing $1.5 \%$ agar). The incubations were carried out at $65^{\circ} \mathrm{C}$ for $24 \mathrm{~h}$.

Routine culturing and strain maintenance. Routine culturing of strain $\mathrm{S} 1812^{\mathrm{T}}$ was performed in Luria broth (LB) containing 0.5 or $1.0 \%$ xylose. The strain was stored in $30 \%$ glycerol at $-20{ }^{\circ} \mathrm{C}$. For routine use, it was preserved on LB agar slants containing $0.5 \%$ xylose at $5{ }^{\circ} \mathrm{C}$.

Cellular and colony characteristics. Colony characteristics were determined from $12 \mathrm{~h}$ cultures grown at $65^{\circ} \mathrm{C}$. Phasecontrast microscopy was used to determine the morphology of cells that had been cultured under different conditions. Electron microscopy of thin sections of strain $\mathrm{S} 1812^{\mathrm{T}}$ was carried out as described previously (Love et al., 1993).

Substrate utilization, biochemical and growth characterization. MM and LB containing different substrates were used to determine the range of substrates utilized by strain S1812 ${ }^{\mathrm{T}}$. Substrates were sterilized separately either by filtration or autoclaving and added to the medium prior to inoculation. Unless indicated otherwise, all incubations were performed at $65^{\circ} \mathrm{C}$. Growth was measured at $580 \mathrm{~nm}$ for up to $72 \mathrm{~h}$. Acid production from carbohydrates was determined by measuring the change in $\mathrm{pH}$ after $72 \mathrm{~h}$ growth.

Temperature growth range $\left(38-75^{\circ} \mathrm{C}\right)$ and $\mathrm{pH}$ growth range $(4 \cdot 0-8 \cdot 0)$ were determined in LB containing $1 \%$ xylose. Media were adjusted to the initial $\mathrm{pH}$ indicated with either $1 \mathrm{M} \mathrm{NaOH}$ or $1 \mathrm{M} \mathrm{HCl}$.

Anaerobic growth was determined according to Gordon et al. (1973). Growth on citrate, xylan, xylose and other pentoses was monitored on MM agar plates supplemented with $1 \%$ of the test substance. Anaerobic growth was also tested in degassed LB medium containing $1 \%$ of the test substance.

Catalase and oxidase were detected by the method of Cowan \& Steel (1974).

Antibacterial inhibition tests. Inhibition of growth of strain $\mathrm{S} 1812^{\mathrm{T}}$ was determined in LB in the presence of sodium azide $(0.02 \%)$, sodium chloride (1-3\%), chloramphenicol $\left(25 \mu \mathrm{g} \mathrm{ml}^{-1}\right)$, streptomycin sulphate $\left(25 \mu \mathrm{g} \mathrm{ml}^{-1}\right)$ and ampicillin $\left(15 \mu \mathrm{g} \mathrm{ml}^{-1}\right)$. Growth was recorded after $3 \mathrm{~d}$ incubation at $65^{\circ} \mathrm{C}$.

DNA base composition. The DNA base composition was determined by thermal denaturation as described previously (Rees et al., 1995). The base composition was calculated following thermal denaturation of the DNA (Mandel \& Marmur, 1968). Escherichia coli DNA was used as the standard.

16S RNA sequence analysis. Purification of genomic DNA, and amplification and purification of the $16 \mathrm{~S}$ rRNA gene (16S rDNA) from strain $\mathrm{S} 1812^{\mathrm{T}}$ were performed by using a technique described previously (Love et al., 1993; Redburn $\&$ Patel, 1993). The purified PCR product was sequenced directly on an ABI automated DNA sequencer using a Prism dideoxy terminator cycle sequencing kit and protocols recommended by the manufacturer (Applied Biosystems).
Using the sequence editor, ae2, the $16 \mathrm{~S}$ rDNA sequence of strain $\mathrm{S} 1812^{\mathrm{T}}$ was aligned with the $16 \mathrm{~S}$ rRNA sequences of various members of the bacterial phyla obtained from the rRNA Database Project (Maidak et al., 1994) and from GenBank. Positions of sequence and alignment uncertainty were omitted from the analysis, and pairwise evolutionary distances for 1332 unambiguous nucleotides were computed. Phylogenetic analysis was performed using programs which form part of the PHYLIP package and include DNADIST (Jukes \& Cantor, 1969), NEIGHBOR-JOINING and DNAPARS (Felsenstein, 1993). Tree topology was re-examined by using 100 bootstrapped data sets for which a script file with the following PHYLIP programs was used: SEQBOOT, DNADIST, FITCH and CONSENSE. Programs in the phylogenetic package MEGA (Kumar et al., 1993) were also used. PHYLIP programs were run on a Sun SPARC work station, and MEGA was run on a Compaq notebook (Contura model 410CX).

DNA-DNA hybridization. The DNA was isolated by chromatography on hydroxyapatite (Cashion et al., 1977). DNA-DNA hybridization was determined at the DSMZ as described by De Ley et al. (1970) with modifications described by Huß et al. (1983) and Escara \& Hutton (1980). A Gilford System model 2600 spectrophotometer equipped with Gilford model 2527-R thermoprogrammer and plotter was used. Renaturation rates were computed with the TRANSFER.BAS program (Jahnke, 1992).

Enzyme assays. D-Xylose, D-xylulose, L-xylulose, D-xylulose 5-phosphate, ribose 5-phosphate, erythrose 4-phosphate, fructose 6-phosphate, ATP, NADH and phosphoenolpyruvate were purchased from Sigma. Pyruvate kinase was from Zymomonas mobilis; lactate dehydrogenase, triose phosphate isomerase and glycerol phosphate dehydrogenase were from rabbit muscle and were purified in our laboratory.

The activities of pentose metabolic enzymes (xylose isomerase, xylulokinase, transaldolase and transketolase) were determined in extracts of strain $\mathrm{S} 1812^{\mathrm{T}}$. For this experiment, the cells were cultivated in LB medium containing either $0.5 \%$ or $1.0 \%$ xylose in a 21 Biostat or in 101 Braun fermenters under $\mathrm{pH}$ and temperature control at $\mathrm{pH} 6.5$ and $65^{\circ} \mathrm{C}$, respectively. Cells were lysed by adding $5 \mathrm{ml}$ of a $25 \mathrm{mM}$ phosphate buffer, $\mathrm{pH} 7 \cdot 0$, containing lysozyme $\left(0 \cdot 2 \mathrm{mg} \mathrm{ml}^{-1}\right)$, DNase $\left(5 \mu \mathrm{g} \mathrm{ml}^{-1}\right)$ and Triton X-100 (0.1\%) to every $g$ (wet weight) of cells. The mixture was stirred gently for $1-3 \mathrm{~h}$ at room temperature. The lysate was centrifuged (20000 $\mathrm{g}$ for $20 \mathrm{~min}$ ) and the clear brownish-red extract was used for enzyme assay. Protein content of the lysate was measured as described by Sedmak \& Grossberg (1977).

Xylulokinase activity was measured using a reaction mixture containing $50 \mathrm{mM}$ Tris/ $\mathrm{HCl}, \mathrm{pH} 8 \cdot 0,10 \mathrm{mM} \mathrm{MgCl}, 1 \mathrm{mM}$ ATP and $2 \mathrm{mM}$ xylulose. After incubation of a sample for $5 \mathrm{~min}$ in $1 \mathrm{ml}$ assay mixture at $60{ }^{\circ} \mathrm{C}, 50 \mu \mathrm{l}$ cold $60 \%$ perchloric acid was added and the denatured protein was removed by centrifugation. After neutralization with $250 \mu \mathrm{l}$ $2 \mathrm{M} \mathrm{KOH}$ containing $50 \mathrm{mM} \mathrm{K}_{2} \mathrm{CO}_{3}$, the amount of ADP that had been formed, compared with a zero time control, was determined with $\mathrm{NADH} /$ phosphoenolpyruvate/ pyruvate kinase/lactate dehydrogenase. Xylose isomerase was measured as described by Lee et al. (1990). Transketolase and transaldolase were measured by stopped procedures at $60{ }^{\circ} \mathrm{C}$, similar to that described above for xylulokinase. For transketolase, $1 \mathrm{mM}$ xylulose 5-phosphate and $2 \mathrm{mM}$ ribose 5-phosphate, and for transaldolase, $1 \mathrm{mM}$ erythrose 4-phosphate and $2 \mathrm{mM}$ fructose 6-phosphate, were 
incubated at $\mathrm{pH} 8$ with extract sample for $5 \mathrm{~min}$ before adding the perchloric acid. Formed glyceraldehyde 3phosphate was measured using $\mathrm{NADH} /$ triose phosphate isomerase/glycerol phosphate dehydrogenase.

Alcohol dehydrogenase was measured at ambient temperature in $50 \mathrm{mM}$ potassium phosphate buffer containing $100 \mathrm{mM}$ ethanol and $1 \mathrm{mM} \mathrm{NAD}^{+}$. All enzyme units are expressed as $\mu \mathrm{mol} \mathrm{min}^{-1}$.

\section{RESULTS}

\section{Enrichment and isolation}

Enrichment cultures, derived from diverse soil samples from garden and compost heaps, were obtained in MM containing xylose following incubation at $65^{\circ} \mathrm{C}$ for $72 \mathrm{~h}$. After several transfers, the enrichment cultures were plated onto LB agar plates. After incubation, several well-isolated colonies that developed were picked. The purified clones were tested individually for their xylose utilization capability and the most efficient strain was selected for further study.

\section{Biochemical characteristics}

Strain S1812 $2^{\mathrm{T}}$ grew well aerobically, but relatively slowly in MM containing xylose as sole carbon source. Because of this slow growth, the bacterium was routinely cultivated in LB medium containing xylose. Strain S1812 ${ }^{\mathrm{T}}$ grew well at $\mathrm{pH} 5 \cdot 5-8 \cdot 0$, with optimum growth at $6 \cdot 8$. Under optimum growth conditions, the generation time was between 24 and $30 \mathrm{~min}$. The strain was a facultative anaerobe, catalase-positive and oxidase-negative. The strain was nutritionally versatile and used a wide variety of carbohydrates when grown on MM, both aerobically and anaerobically. It did not grow on citrate and grew poorly on lactate (Table 1).

\section{Morphology}

Strain $\mathrm{S} 1812^{\mathrm{T}}$ formed small colonies with entire margins after overnight incubation at $65^{\circ} \mathrm{C}$ on $\mathrm{LB}$ plates with or without xylose. Light microscopy revealed that the strain was a rod-shaped and sporu-

Table 1. Physiological and biochemical properties of S. caldoxylosilyticus strain $S 1812^{\top}$ and $S$. thermophilus

+ , Growth/activity observed; -, no growth/activity observed; w, weak growth; ND, not determined. Both strains produced catalase. Neither strain grew on citrate, but both strains grew on the following substrates: arabinose $\dagger$, galactose $\dagger$, glucose $\dagger$, glycerol, mannitol, mannose $\dagger$, rhamnose $\dagger$, sorbitol and xylose $\dagger$ ( $\dagger$ indicates anaerobic growth observed with $\mathrm{S}_{1812^{\mathrm{T}}}$ ).

\begin{tabular}{|lcc|}
\hline Character & $\begin{array}{c}\text { S. caldoxylosilyticus } \\
\text { strain } \mathbf{S 1 8 1 2}\end{array}$ & $\begin{array}{c}\text { S. thermophilus } \\
\text { CCM 3586* }\end{array}$ \\
\hline Morphology: & Rods & Cocci \\
Cell shape & Sporulating & Non-sporulating \\
Spores & 44 & 48 \\
G + C content (mol \%) & & \\
Physical growth conditions: & 65 & 70 \\
Optimum temperature $\left({ }^{\circ} \mathrm{C}\right)$ & $6 \cdot 5$ & $7 \cdot 0$ \\
Optimum pH & + & - \\
Anaerobic growth & & \\
Biochemical pattern: & - & ND \\
Oxidase & - & ND \\
NaCl $(3 \%)$ & - & ND \\
Sodium azide $(0 \cdot 02 \%)$ & & - \\
Carbon sources tested $(\mathrm{MM}):$ & + & ND \\
Cellobiose $\dagger$ & + & - \\
Glycogen & $\mathrm{w}$ & - \\
Lactate & + & - \\
Lactose & + & ND \\
Raffinose & + & ND \\
Starch $\dagger$ & + & ND \\
Sucrose & + & \\
Trehalose & + & \\
Xylan $\dagger$ & &
\end{tabular}

* Data from Nystrand (1984).

$\uparrow$ Anaerobic growth observed with S1812 ${ }^{\mathrm{T}}$. 


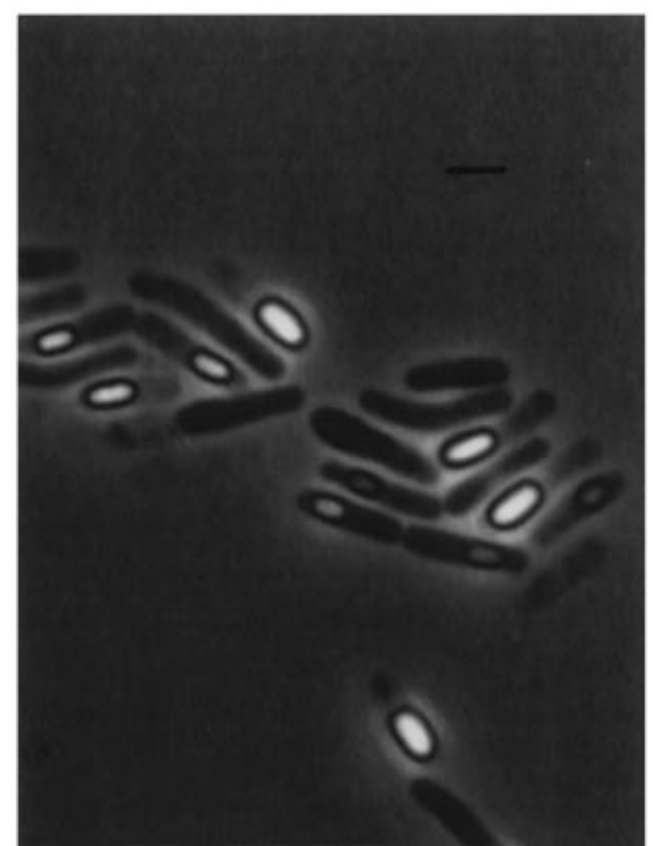

Fig. 1. Phase-contrast photomicrograph of strain $\mathrm{S} 1812^{\top} \cdot \mathrm{Bar}$, $2 \mu \mathrm{m}$.

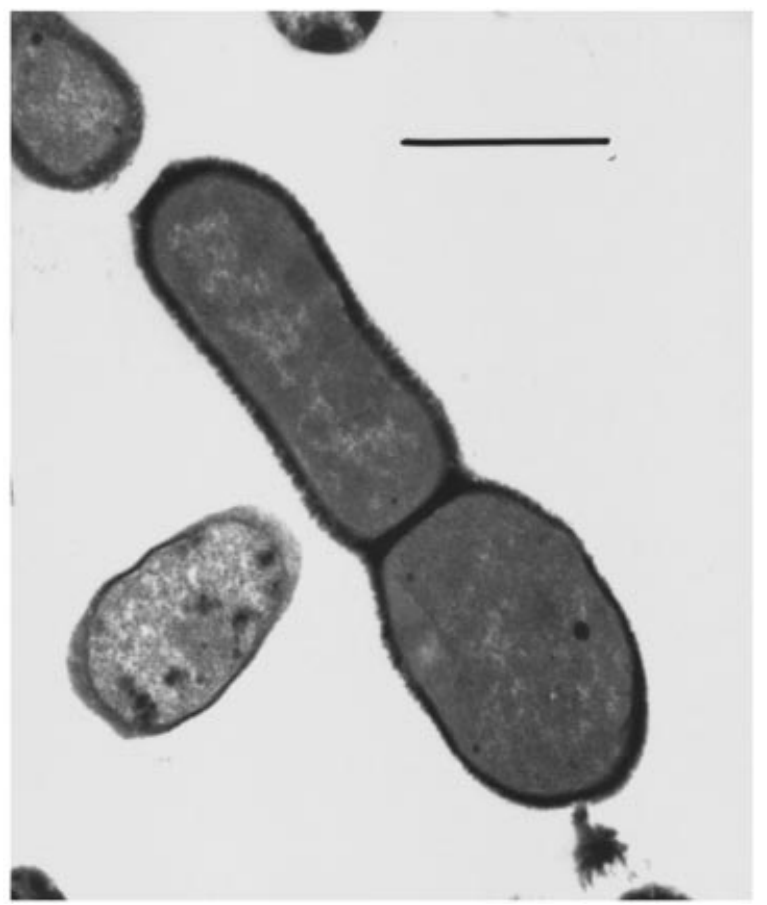

Fig. 2. Electron micrograph of an ultrathin section of strain S1812 ${ }^{\top}$ showing the cell wall structure. Bar, $2 \mu \mathrm{m}$.

lating Bacillus. This was subsequently confirmed by electron microscopy (Figs 1 and 2), which revealed cells $2 \cdot 1 \mu \mathrm{m}$ long and $0.6 \mu \mathrm{m}$ wide, and ellipsoidal spores $1 \cdot 2 \mu \mathrm{m}$ long and $0 \cdot 6-0 \cdot 7 \mu \mathrm{m}$ wide. The spores were central to terminal in location.

\section{Salt and antibiotic sensitivity}

Growth was inhibited in the presence of $3 \% \mathrm{NaCl}$, sodium azide $(0.02 \%)$, chloramphenicol $\left(25 \mu \mathrm{g} \mathrm{ml}^{-1}\right)$, streptomycin sulphate $\left(25 \mu \mathrm{g} \mathrm{ml}^{-1}\right)$ and ampicillin $\left(15 \mu \mathrm{g} \mathrm{ml}^{-1}\right)$.

\section{G + C content of DNA and DNA hybridization studies}

The $\mathrm{G}+\mathrm{C}$ content of this strain is $44.4 \mathrm{~mol} \%$, which is significantly lower than that of most other obligately thermophilic Bacillus spp., which exhibit $\mathrm{G}+\mathrm{C}$ values higher than $52 \mathrm{~mol} \%$ (Sharp et al., 1980). However, some thermophilic Bacillus species, such as Bacillus thermoglucosidasius, do exhibit $\mathrm{G}+\mathrm{C}$ values around $44 \mathrm{~mol} \%$ (White et al., 1993). The value for Saccharococcus thermophilus is reported to be $48 \mathrm{~mol} \%$ (Nystrand, 1984).

The results of the DNA hybridization studies are shown in Table 2. The relationship with B. stearothermophilus and 'Bacillus thermodenitrificans' is fairly distant, but is close with $S$. thermophilus, and at $67 \%$, hybridization is much stronger with $S$. thermophilus than with the Bacillus spp. studied.

\section{S rRNA sequence}

A sequence consisting of $1516 \mathrm{nt}$ of the 16S rRNA gene of strain $\mathrm{S} 1812^{\mathrm{T}}$ was determined. The sequence positions 14-1516 [E. coli numbering according to Winker \& Woese (1991)] were aligned with representatives of the various phyla of the domain Bacteria and phylogenetic analysis was performed. Several data sets which included different representatives from the various phyla of the domain Bacteria were also created and, in all cases, strain $\mathrm{S} 1812^{\mathrm{T}}$ was consistently placed as a peripheral member of the thermophilic Bacillus species cluster 5 , in the sub-branch of the low- $\mathrm{G}+\mathrm{C}$ Gram-positive bacteria as defined by Ash et al. (1991). The evolutionary distances separating strain $\mathrm{S} 1812^{\mathrm{T}}$ and its relatives, and the dendrogram derived from evolution distances is depicted in Fig. 3. Transversion analysis did not affect the relationship of strain $\mathrm{S} 1812^{\mathrm{T}}$ with its nearest relatives.

Extracts of the cells were tested for various enzyme activities associated with xylose utilization. Xylose isomerase and xylulokinase activities were high in cells grown either on xylose or on glucose, indicating perhaps that the $X y l \mathrm{~A}-X y / \mathrm{B}$ operon was constitutive rather than inducible. Transketolase and transaldolase were induced only in the presence of xylose (Table 3).

Alcohol dehydrogenase activity (specific activity up to 20 units $\mathrm{mg}^{-1}$ at $60{ }^{\circ} \mathrm{C}$ ), was found to be present only in anaerobically grown cells. It was not detected at a sensitivity of 0.5 units $\mathrm{mg}^{-1}$ in extracts of fully aerobic cells. This alcohol dehydrogenase has been isolated ( $\mathrm{J}$. 
Table 2. DNA-DNA hybridization

Similarities (\%) are given.

\begin{tabular}{|c|c|c|c|}
\hline & $\begin{array}{c}\text { Saccharococcus } \\
\text { caldoxylosilyticus strain } \\
\mathbf{S 1 8 1 2}^{\mathrm{T}}\end{array}$ & $\begin{array}{c}\text { Bacillus } \\
\text { stearothermophilus } \\
\text { DSM } 22\end{array}$ & $\begin{array}{c}\text { 'Bacillus } \\
\text { thermodenitrificans, } \\
\text { DSM } 465\end{array}$ \\
\hline B. stearothermophilus DSM 22 & $33 \cdot 4$ & & \\
\hline 'B. thermodenitrificans' DSM 465 & $37 \cdot 0$ & $48 \cdot 3$ & \\
\hline Saccharococcus thermophilus DSM 4749 & $67 \cdot 0$ & $45 \cdot 2$ & $44 \cdot 0$ \\
\hline
\end{tabular}

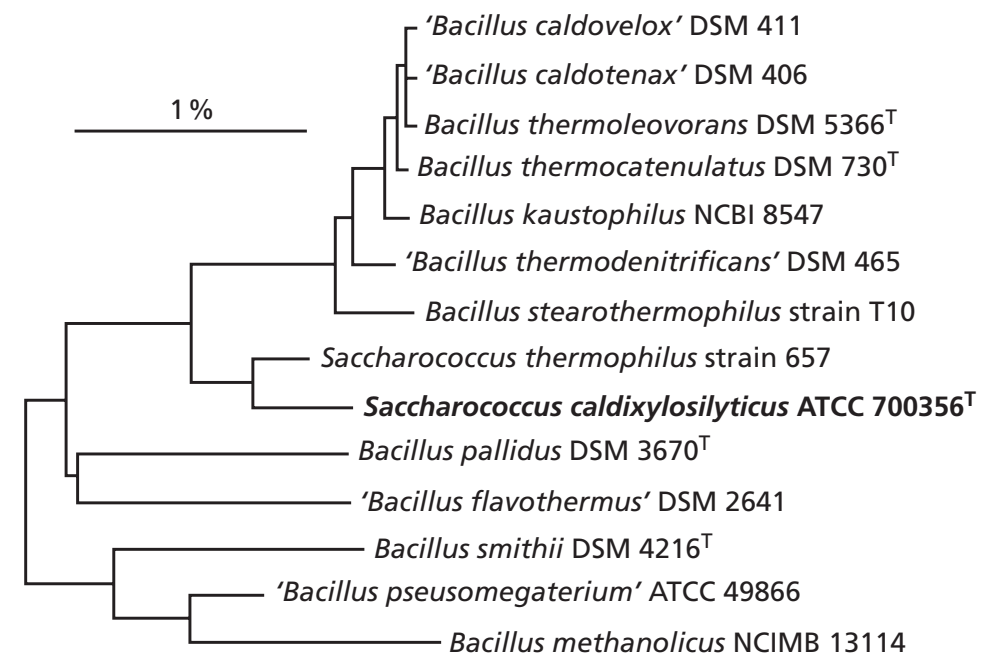

Fig. 3. Dendrogram indicating the position of strain $\mathrm{S}_{1812^{\top}}$ amongst the representatives of the members of the low-G + C Grampositive Bacillus groups (cluster 5 according to Ash et al., 1991). The dendrogram was derived from the evolutionary distance matrix as described in Methods. Bar, 1 substitution per 100 nucleotides.

Scoble, personal communication) and found to have a versatile substrate specificity and to be similar in characteristics to the $B$. stearothermophilus enzyme described by Guagliardi et al. (1996). However, the latter was reportedly isolated from aerobically grown cells.

\section{DISCUSSION}

Initial studies indicated that $\mathrm{S} 1812^{\mathrm{T}}$ was a member of Bacillus cluster 5 as defined by Ash et al. (1991). On the basis of genotypic and phenotypic properties, the isolate can be clearly distinguished from other described Bacillus species. Despite the morphological observations that clearly class this bacterium as a Bacillus, its closest relative based on 16S rRNA sequence analysis and on DNA-DNA hybridization is $S$. thermophilus. Phylogenetic analysis of $S$. thermophilus (Nystrand, 1984; Rainey \& Stackebrandt, 1993) and other non-spore-forming rods such as Filibacter limicola (Clausen et al., 1985) and Caryophanon latum (Stackebrandt et al., 1987) has suggested that these Gram-positive bacteria are closely related to Bacillus species and can be considered as offshoots. The $16 \mathrm{~S}$
rRNA sequence showed that $\mathrm{S} 1812^{\mathrm{T}}$ shared a common ancestry with members of the bacillus cluster group 5, as defined by Ash et al. (1991), as well as an even closer relationship with $S$. thermophilus. Furthermore, DNA-DNA hybridization has shown its relatively distant relationship to B. stearothermophilus $(33.4 \%)$ and ' $B$. thermodenitrificans' $(37 \cdot 0 \%)$ and its closeness to $S$. thermophilus $(76 \cdot 0 \%)$.

It is not unusual that phylogeny does not reflect phenotypic properties. It has been reported that Deinobacter, a rod-shaped bacterium, is more phylogenetically related to Deinococcus, a coccus-shaped bacterium, and hence was transferred as a member of the Deinococcus (Oyaizu et al., 1987; Rainey et al., 1997). The similarity of $S 1812^{\mathrm{T}}$ to $S$. thermophilus is at the borderline of species level, but the cell morphology is completely different. In addition, several phenotypic characteristics differentiate the two strains (Table 1).

The isolation of this xylolytic thermophile was initiated as part of a study into thermophilic ethanol fermentations. Although the strain does possess an alcohol dehydrogenase, and so presumably makes alcohol under certain conditions, this enzyme is entirely absent 
Table 3. Metabolic enzymes of xylose utilization in S. caldoxylosilyticus $S 1812^{\top}$ cells

Cells were grown in LB medium for $24 \mathrm{~h}$ at $60^{\circ} \mathrm{C}$ with $1 \%$ xylose or glucose. Enzyme activity was determined from crude cell lysate and is shown as units (mg protein $)^{-1}$ at $60^{\circ} \mathrm{C}$. Figures for transaldolase and transketolase are indicative only, as several side reactions occur during the incubations.

\begin{tabular}{|lcccc|}
\hline $\begin{array}{l}\text { Carbon } \\
\text { source }\end{array}$ & $\begin{array}{c}\text { Xylose } \\
\text { isomerase }\end{array}$ & Xylulokinase & Transketolase & Transaldolase \\
\hline Xylose & $0 \cdot 8$ & $3 \cdot 1$ & $1 \cdot 0$ & $0 \cdot 8$ \\
Glucose & $0 \cdot 6$ & $3 \cdot 0$ & $0 \cdot 2$ & $0 \cdot 1$ \\
\hline
\end{tabular}

when the cells are grown aerobically. Unusually, the first two enzymes of xylose utilization, xylose isomerase and xylulokinase, were present at high levels even when the cells were grown on glucose. On the other hand, transketolase and transaldolase were strongly induced by growth on xylose. It appears that this organism has potential as a high-temperature producer of ethanol from lignocellulose hydrolysates when fermented anaerobically if additional alcohol dehydrogenase and pyruvate decarboxylase enzymes can be introduced genetically.

Based on the evidence presented, it is proposed to designate strain $\mathrm{S} 1812^{\mathrm{T}}$ Saccharococcus caldoxylosilyticus.

\section{Description of Saccharococcus caldoxylosilyticus sp. nov.}

Genus Saccharococcus: the description of the genus is essentially as described by Nystrand (1984) but is amended to now include phylogenetic relatives which possess rod-shaped morphologies.

Saccharococcus caldoxylosilyticus (cal.do.xy.lo.si. ly'ti.cus. L. adj. caldus hot; M.L. neut. N. xylosum xylose; M.L. adj. lyticus dissolving, degrading; caldoxylosilyticus hot and xylose-degrading).

Gram-positive rods, $0 \cdot 8-0 \cdot 9$ by $2 \cdot 3 \mu \mathrm{m}$, occurs singly, in pairs or chains. Central to terminal endospore ellipsoidal; sporangium slightly swollen. Colonies flat to convex, round or lobed, smooth, opaque. Growth between 43 and $75^{\circ} \mathrm{C}$; optimal growth at $65^{\circ} \mathrm{C}$, $\mathrm{pH}$ 6.8-7.2. Generation time under optimum conditions 24-30 min. Facultative anaerobe. DNA G + C content of $44.4 \mathrm{~mol} \%$. Habitat: soil. Type strain is Saccharococcus caldoxylosilyticus $\mathrm{S} 1812^{\mathrm{T}}$ and has been deposited in the American Type Culture Collection (ATCC), Manassas, VA 20852, USA under number ATCC $700356^{\mathrm{T}}$.

\section{ACKNOWLEDGEMENTS}

The Postdoctoral Fellowship award (to S. A.) and research grant from Energy Research \& Development Council (to R.K.S.) is duly acknowledged. Funding in part from the Australian Research Council (to B.K.C.P.) is gratefully acknowledged.

\section{REFERENCES}

Ash, C., Farrow, J. A. F., Wallbanks, S. \& Collins, M. D. (1991). Phylogenetic heterogeneity of the genus Bacillus revealed by comparative analysis of small-subunit ribosomal RNA. Lett Appl Microbiol 13, 202-206.

Cashion, P., Holder-Franklin, M. A., McCully, J. \& Franklin, M. (1977). A rapid method for base ratio determination of bacterial DNA. Anal Biochem 81, 461-466.

Clausen, V., Jones, J. G. \& Stackebrandt, E. (1985). 16S rRNA analysis of Filibacter limicola indicates a close relationship to the genus Bacillus. J Gen Microbiol 131, 2659-2663.

Cowan, S. T. \& Steel, K. J. (1974). Manual for the Identification of Medical Bacteria, 2nd edn. Cambridge: Cambridge University Press.

De Ley, J., Cattoir, H. \& Reynaerts, A. (1970). The quantitative measurement of DNA hybridisation from renaturation rates. Eur J Biochem 12, 133-142.

Escara, J. F. \& Hutton, J. R. (1980). Thermal stability and renaturation of DNA in dimethylsulphoxide solutions: acceleration rate. Biopolymers 19, 1315-1327.

Felsenstein, J. (1993). PHYLIP (Phylogenetic Inference Package) version 3.51c. Distributed by the author. Department of Genetics, University of Washington, Seattle, WA, USA.

Gordon, R. E., Haynes, W. C. \& Pang, C. H.-N. (1973). The Genus Bacillus (Agricultural Handbook no. 427). Washington, DC: United States Department of Agriculture.

Guagliardi, A., Martino, M., laccarino, I., de Rosa, M., Rossi, M. \& Bartolucci, S. (1996). Purification and characterization of the alcohol dehydrogenase from a novel strain of Bacillus stearothermophilus growing at $70^{\circ} \mathrm{C}$. Int J Biochem Cell Biol 28, 239-246.

Huß, V. A. R., Festl, H. \& Schleifer, K. H. (1983). Studies on the spectrophotometric determination of DNA hybridisation from renaturation rates. Syst Appl Microbiol 4, 184-192.

Jahnke, K.-D. (1992). Basic computer program for evaluation of spectroscopic DNA renaturation data from Gilford Syst 2600 spectrophotometer on a $\mathrm{PC} / \mathrm{XT} / \mathrm{AT}$ type personal computer. J Microbiol Methods 15, 61-73.

Jukes, T. H. \& Cantor, C. R. (1969). Evolution of protein molecules. In Mammalian Protein Metabolism, vol. 3, pp. 21-132. Edited by H. N. Munro. New York: Academic Press.

Kumar, S., Tamura, K. \& Nei, M. (1993). MEGA: Molecular Evolutionary Genetic Analysis, version 1.0. The Pennsylvania State University, University Park, PA 16802, USA.

Lee, C., Bagdasarian, M., Meng, M. \& Zeikus, J. G. (1990). Catalytic mechanism of xylose (glucose) isomerase from Clostridium thermosulfurogenes. J Biol Chem 265, 19082-19090. 
Love, C. A., Patel, B. K. C., Nichols, P. D. \& Stackebrandt, E. (1993). Desulfotomaculum australicum sp. nov., a thermophilic sulfatereducing bacterium isolated from the Great Artesian Basin of Australia. Syst Appl Microbiol 16, 244-251.

Maidak, B. L., Larsen, N., McCaughey, M. J., Overbeek, R., Olsen, G. J., Fogel, K., Blandy, J. \& Woese, C. R. (1994). The Ribosomal Database Project. Nucleic Acids Res 22, 3485-3487.

Mandel, M. \& Marmur, J. (1968). Use of ultraviolet absorbancetemperature profile for determining the guanine plus cytosine content of DNA. In Methods in Enzymology Vol. XII. Nucleic Acids, part B. Edited by L. Grossman \& K. Moldave. New York/London: Academic Press.

Miquel, P. (1888). Monographie d'un bacille vivant au-dela de $70{ }^{\circ} \mathrm{C}$. Ann Micrographic 1, 3 .

Neale, A. D., Scopes, R. K. \& Kelly, J. M. (1988). Alcohol production from glucose and xylose using Escherichia coli containing Zymomonas mobilis genes. Appl Microbiol Biotechnol 29, 162-167.

Nystrand, R. (1984). Saccharococcus thermophilus gen. nov., sp. nov. Isolated from beet sugar extraction. Syst Appl Microbiol 5, 204-219.

Oyaizu, H., Stackebrandt, E., Schleifer, K. H., Ludwig, W., Pohla, H., Ito, H., Hirata, A., Oyaizu, Y. \& Komagata, K. (1987). A radiation-resistant rod shaped bacterium Deinobacter grandis gen. nov., sp. nov., with peptidoglycan containing ornithine. Int J Syst Bacteriol 37, 62-67.

Rainey, F. A. \& Stackebrandt, E. (1993). Phylogenetic evidence for the relationship of Saccharococcus thermophilus to Bacillus stearothermophilus. Syst Appl Microbiol 16, 224-226.
Rainey, F. A., Nobre, M. F., Schumann, P., Stackebrandt, E. \& da Costa, M. S. (1997). Phylogenetic diversity of the Deinococci as determined by $16 \mathrm{~S}$ ribosomal DNA sequence comparison. Int $J$ Syst Bacteriol 47, 510-514.

Redburn, A. C. \& Patel, B. K. C. (1993). Phylogenetic analysis of Desulfotomaculum thermobenzoicum using polymerase chain reaction-amplified 16S rRNA-specific DNA. FEMS Microbiol Lett 113, 81-86.

Rees, G. N., Grassia, G. S., Sheehy, A. J., Dwivedi, P. P. \& Patel, B. K. C. (1995). Desulfacinum infernum gen. nov., sp. nov., a thermophilic sulfate reducing bacterium from a petroleum reservoir. Int J Syst Bacteriol 45, 85-89.

Sedmak, J. J. \& Grossberg, S. E. (1977). A rapid and versatile assay for protein using Coomassie Brilliant Blue G 250. Anal Biochem 79, 544-552.

Sharp, R. J., Bown, K. J. \& Atkinson, A. (1980). Phenotypic and genotypic characterization of some thermophilic species of Bacillus. J Gen Microbiol 117, 201-210.

Stackebrandt, E., Ludwig, W., Weizenegger, M., Dorn, S., MacGill, T. J., Fox, G. E., Woese, C. R., Schubert, W. \& Schleifer, K. H. (1987). Comparative 16S rRNA oligonucleotide analyses and murin types of round-spore-forming bacilli and nonsporeforming relatives. J Gen Microbiol 133, 2523-2529.

White, D., Sharp, R. J. \& Priest, F. G. (1993). A polyphasic taxonomic study of thermophilic bacilli from a wide geographical area. Antonie Leeuwenhoek 64, 357-386.

Winker, S. \& Woese, C. R. (1991). A definition of the domains Archaea, Bacteria and Eucarya in terms of small subunit ribosomal RNA characteristics. Syst Appl Microbiol 13, $161-165$. 